\title{
Effect of Whey Protein Isolate on the Properties of Freeze Dried aloe vera (Aloe barbadensis Mill) Powder
}

\author{
Ankit Dayal $^{*}{ }^{*}$, Anju Bhat ${ }^{1}$, Rafia Rashid ${ }^{1}$, Jagmohan Singh ${ }^{1}$ and Sushil Sharma ${ }^{2}$ \\ ${ }^{1}$ Division of Food Science and Technology, ${ }^{2}$ Division of Agricultural Engineering, Sher-e- \\ Kashmir University of Agricultural Sciences and Technology of Jammu, \\ Jammu and Kashmir, India \\ *Corresponding author
}

\section{A B S T R A C T}

\begin{tabular}{|l|}
\hline Ke y w or d s \\
$\begin{array}{l}\text { Aloe vera, Whey } \\
\text { protein, Freeze } \\
\text { drying, Density }\end{array}$ \\
\hline Article Info \\
\hline $\begin{array}{l}\text { Accepted: } \\
16 \text { March } 2018 \\
\text { Available Online: } \\
10 \text { April } 2018\end{array}$ \\
\hline
\end{tabular}

\section{Introduction}

Drying of fruits is one of the oldest techniques of food preservation known to man for example solar drying. One of the essential feature of drying is that the moisture content is reduced to a level $(<5 \%)$ below which microorganisms can't grow. Freeze-drying, also known as lyophilization or cryodesiccation, has been proven as the best method for drying thermosensitive substances. This method minimizes thermal degradation reactions. It is comparatively costly method
The effect of whey protein isolate concentrations $(10 \%, 15 \%$ and $20 \%)$ as carrier agent on isolate in aloe vera juice yielded powder with free flowable properties. The moisture content and water activity of the freeze dried powder decreased with incorporation of carrier agent. Colour properties observed on the basis of $\mathrm{L}^{*}, \mathrm{a}^{*}$ and $\mathrm{b}^{*}$ revealed that lightness $\left(\mathrm{L}^{*}\right)$ of the powder increased with incorporation of whey protein while $\mathrm{a}^{*}$ and $\mathrm{b}^{*}$ decreased. Highest $\mathrm{L}^{*}$ values (86.87) was observed at $20 \%$ of concentration. Water solubility, swelling capacity, dissolution time, tapped and bulk density increased whereas the water absorption index, hygroscopicity and cohesiveness measured in terms of Hausner ratio of the powder decreased with incorporation of whey protein. Powder recovery improved with addition and increasing concentration of whey protein. Carr index and Hausner ratio measured showed the better flow properties of the powder. Storage period significantly affected the physical and functional properties of the powder. but the high value of nutraceutical extract and ability to encapsulate heat sensitive compounds could justify such costs (LopezQuiroga et al., 2012).

Aloe vera (Aloe barbadensis Miller) originated in the warm, dry climates of Africa. Aloe is a member of liliaceae family and it resembles-cactus. Aloe vera is an important and traditional medicinal plant and has been used for its medicinal value for several thousand years. Its applications have been recorded in ancient cultures of India, Egypt, 
Greece, Rome and China. Aloe vera is known by several names, it is commonly known as ghrit kumari or gawarpatha in India. Aloe vera leaf contains two major liquid sources, yellow latex (exudate) and the clear gel (mucilage). The mucilaginous jelly from the parenchyma cells of the plant is referred to as aloe vera gel (Eshun and He, 2004).

Photochemistry of aloe vera gel has revealed the presence of vitamins, minerals, enzymes, sugars, polysaccharides, anthraquinones of phenolic compounds (Pugh et al., 2001). Aloe vera has been utilized as a source of functional food, especially for the preparation of health food drinks and other beverages (Ramachandra and Rao, 2008).

Various carrier agents (maltodextrin, starch, modified starch and protein conjugates, gums, pectin, etc.) are available for the use in food. The ideal encapsulant should have filmforming properties, emulsifying properties, be biodegradable, be resistant to the gastrointestinal tract, have low viscosity at high solids contents, exhibit low hygroscopicity and have a low cost (RochaParra et al., 2016). Whey, major by-product from dairy industry, has good emulsifying properties and plays a protective role against thermal effects (Bernard, et al., 2011). Whey protein form smooth and non- sticky films or shells much earlier than other drying aid resulting higher recovery of powders in a small amount of proteins being spray dried (Bhusari et al., 2014).

\section{Materials and Methods}

\section{Materials}

Fresh and mature leaves of aloe vera and were whey protein isolate purchased from local market. Laboratory scale freeze dryer (Alpha 2-4 LDplus by Martin Christ) was employed for the freeze drying of aloe vera juice.

\section{Methods}

\section{Processing of aloe vera juice}

Aloe vera gel was extracted using using hand filleted technique and processed into juice. Leaves were dipped in 500 ppm potassium metabisulphite (KMS) solution for an hour and then washed thoroughly with tap water followed by cooling of leaves at $5^{\circ} \mathrm{C}$ for gel stabilization. Tapering tip and lower leaf base of Aloe vera leaves were trimmed off (1-2 inch) and the sharp spikes located along the leaf margins were also removed with the help of a sharp stainless steel knife. Thereafter, green rind portion (epidermis) was carefully separated from the parenchyma (inner fillet) by knife to avoid mixing of gel with yellow latex, located between the rind and the inner fillet. These fillets were then passed through the juicer to get the aloe vera juice. The aloe vera juice was filtered through sieve to remove coarse particle. The aloe vera juice obtained was mixed with whey protein isolate (WPI) at the concentrations of 10\%, $15 \%$ and $20 \%$. Then it was subjected to lyophilization (61 to $-65{ }^{\circ} \mathrm{C}$ for 72 hours). The aloe vera powder obtained after the lyophilization was coded as $\mathrm{T}_{1}, \mathrm{~T}_{2}$ and $\mathrm{T}_{3}$ for on the basis of carrier agent concentration i.e. 10\%, 15\% and $20 \%$ respectively. The powder was packed in laminated pouches and stored under room conditions.

\section{Physico-chemical properties}

The moisture content was determined by using an electronic moisture analyzer (MB 54, Citizen). The water activity was determined using water activity meter (Aqua Lab, Decagon devices, USA). For hygroscopicity, $1.5 \mathrm{~g}$ of the powder was placed in an airtight container containing saturated solution of sodium carbonate. Sample was weighed after 1 week and hygroscopicity was expressed (Cai and Corke, 2000). For dissolution test, $50 \mathrm{mg}$ 
of powder sample was taken in a test tube. 1 $\mathrm{ml}$ of distilled water was added and was mixed by vortexing. The time (s) to fully reconstitute the powders was recorded (Quek et al., 2007). The colour parameters of the encapsulated powder were determined using Hunter lab colorimeter (Patras et al., 2011).

\section{Functional properties}

$2.5 \mathrm{~g}$ powder was suspended in $50 \mathrm{ml}$ tared centrifuge tubes containing $30 \mathrm{ml}$ of distilled water. The sample was stirred intermittently over a period of 30 minutes and centrifuged at $3000 \mathrm{rpm}$ for $10 \mathrm{~min}$. The supernatant obtained was poured carefully into a tared evaporating dish for further calculation (eqn. 2) of water solubility index (Anderson et al., 1969). The remaining gel was weighed and the water absorption index was calculated (eqn 1). Swelling capacity was determined using the equation 3 (Lai and Cheng, 2004). Two grams of powder was loaded into a $10 \mathrm{ml}$ graduated cylinder and the volume occupied was recorded to calculate the bulk density (eqn 4) (Sansone et al., 2011). Tapped density by placing two grams of powder in a $10 \mathrm{ml}$ graduated cylinder and calculating the volume after the sample was smoothly dropped 120 times on top of a rubber mat from a height of $15 \mathrm{~cm}$ (Ozdikicierler et al., 2014). The flowability and cohesiveness (Table 1) of the powder, expressed as Carr index (CI \%) and Hausner ratio (HR) respectively and was calculated from tapped $(\rho T)$ and bulk density ( $\rho \mathrm{B})$ (eqn 5 and 6) (Jinapong et al., 2008).

$$
\begin{aligned}
& \text { Water absorption index }=\frac{\text { weight of gel }- \text { weight of ground dry sample }}{\text { weight of ground dry sample }} \\
& \text { Water solubility index }(\%)=\frac{\text { weight of dry solids from the supernatant }}{\text { weight of ground dry sample }} \times 100 \\
& \text { Swelling capacity }=\frac{\text { Dry weight }}{\text { Drypernatent }}
\end{aligned}
$$

$$
\begin{aligned}
& \text { Bulk density }=\frac{\text { Mass of powder }}{\text { volume }} \\
& \mathrm{CI}(\%)=\frac{\rho \mathrm{T}-\mathrm{\rho B}}{\mathrm{\rho T}} \\
& \mathrm{HR}=\frac{\mathrm{pT}}{\mathrm{pB}}
\end{aligned}
$$

\section{Powder recovery/yield}

Powder recovery/yield, was evaluated by determination of the product recovery given by the percentage ratio between the total mass of product recovery and the mass of extract, fed in the system (Fazaeli et al., 2012).

\section{Statistical analysis}

Three replications of the samples for each test were performed and the data recorded was calculated by factorial-CRD (completely randomized design).

\section{Results and Discussion}

\section{Moisture content}

Moisture content of aloe vera powder differed significantly in all the treatments. The highest moisture content $(3.74 \%)$ was observed in $\mathrm{T}_{1}$ and the lowest $(3.40 \%)$ in $\mathrm{T}_{3}$. Incorporation and increased concentration of WPI increased the total solids in juice to be dried which in turn reduced the total water available for evaporation, thus decreased the moisture content. Moisture content decreases with incorporation and increasing concentration of WPI (Bhusari et al., 2014).

\section{Water activity $\left(\mathbf{a}_{\mathbf{w}}\right)$}

Water activity $\left(\mathrm{a}_{\mathrm{w}}\right)$ was maximum $(0.169)$ in treatment $T_{1}$ and the lowest $(0.142)$ in $T_{3}$. Water activity of the powders decreased with incorporation of carrier agent and increase in their concentrations. This might be due to the 
increased total solids like in case of moisture content. Drying aids reduced the water activity in ginger powder (Phoungchandang and Sertwasana, 2010). Water activity decreased with increased concentration of carrier agents (Bhusari et al., 2014).

\section{Water absorption index}

The data (Table 2) revealed that different concentrations of carrier agent and storage period significantly affected the water absorption index of freeze dried aloe vera powder. Highest water absorption index (3.36 $\mathrm{g} / \mathrm{g}$ ) was recorded in $\mathrm{T}_{1}$ and the lowest (2.99 $\mathrm{g} / \mathrm{g}$ ) was in $\mathrm{T}_{3}$. With the increase in concentration of carrier agents, water absorption index of the powder decreased. Carrier agents decreased the water absorption index in Satureja montana powders (Vidovic et al., 2014). These effects of carrier agents may be attributed to the inverse relationship between the carrier agent's concentration and the mean particle size (Adhikari et al., 2003). Carrier agents decreased the water absorption index in encapsulated bioactive components of purple sweet potato (Ahmed et al., 2010).

\section{Water solubility index / solubility index}

Maximum water solubility index $(87.23 \%)$ was recorded in $\mathrm{T}_{3}$ and the lowest (84.01\%) in $\mathrm{T}_{1}$. The addition of carrier agents seemed to improve the solubility of the powder which might be attributed to the fact that carrier agent had superior water solubility (Goula and Adampoulos, 2008). Similar results were observed in freeze dried anthocyanin powder (laokuldilok and Kanha, 2015).

\section{Swelling capacity}

From the data (Table 2), it is evident that the highest swelling capacity $(2.98 \mathrm{ml} / \mathrm{g})$ was recorded in $\mathrm{T}_{3}$ and the lowest $(2.62 \mathrm{ml} / \mathrm{g})$ in $\mathrm{T}_{1}$. The swelling capacity of the powders increased with WPI, this might be due to the starch-water interactions (Ahmed et al., 2010; Gunaratne and Hoover, 2002). Amylopectin fraction of starch is believed to be primarily responsible for swelling (Vanzo et al., 2009).

\section{Hygroscopicity}

Hygroscopicity is a measurement of the capacity of the food to contain occluded moisture and is an important property, to be considered during the storage of the product (Rodríguez-Hernández et al., 2005). Higher hygroscopicity $(7.96 \mathrm{~g} / 100 \mathrm{~g})$ was in $\mathrm{T}_{1}$ and the lowest $(6.02 \mathrm{~g} / 100 \mathrm{~g})$ was in $\mathrm{T}_{3}$. With the increase in concentration, hygroscopicity decreased which might be due to the low moisture content. Increased concentration of carrier agent decreased the hygroscopicity of the tamarind pulp powder and beetroot juice concentrate respectively (Bazaria et al., 2016; Bhusari et al., 2014).

\section{Dissolution}

Dissolution test is the measurement of the reconstitution speed of dried powder into water. It is expressed as the time taken by the powder to fully reconstitute in water by vortexing (Quek et al., 2007). Increase in dissolution time with increase in concentration was recorded.

Highest (21.67 s) dissolution time was recorded in $\mathrm{T}_{3}$ and the lowest (15.67 s) in $\mathrm{T}_{1}$, this might be due to increase in total solids in the powder. Increased concentration of carrier agent increased the dissolution time in freeze dried watermelon powder (Oberoi and Sogi, 2015).

\section{$\operatorname{Colur}\left(\mathbf{L}^{*}, \mathbf{a}^{*}\right.$ and $\left.\mathbf{b}^{*}\right)$}

Colour is a very important quality characteristic of fruit and vegetable products which influences the consumer acceptability. 
Fig.1 Bulk and tapped density of the freeze dried aloe vera powder

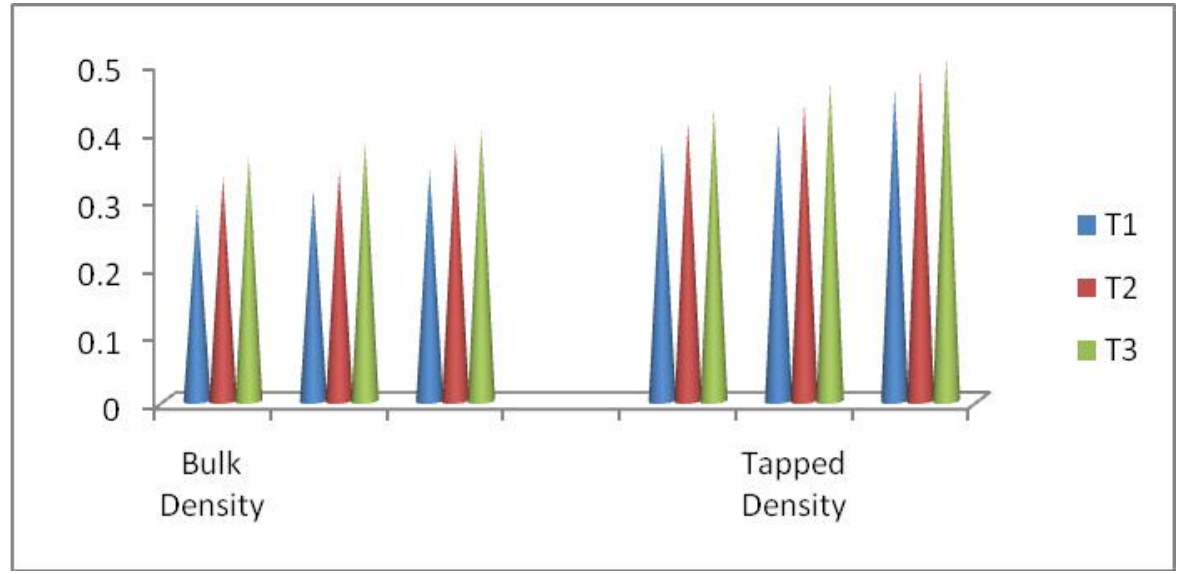

Fig.2 Cohesiveness (Hausner ratio) of freeze dried aloe vera powder

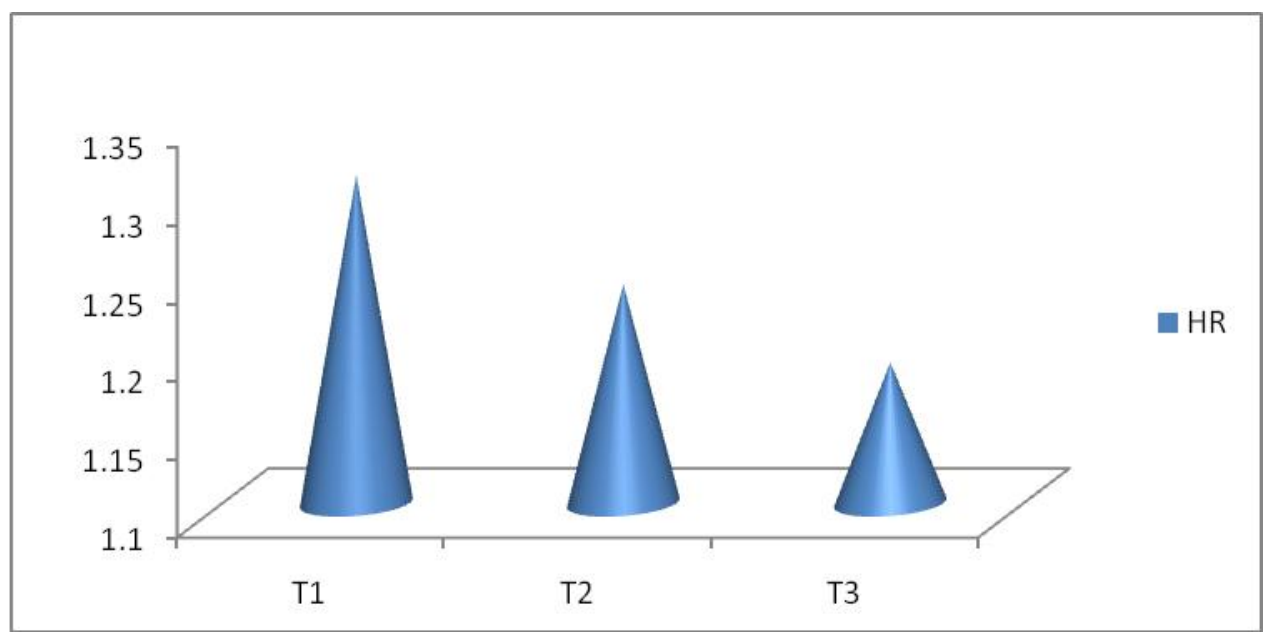

Fig.3 Carr index (CI\%) of freeze dried aloe vera powder

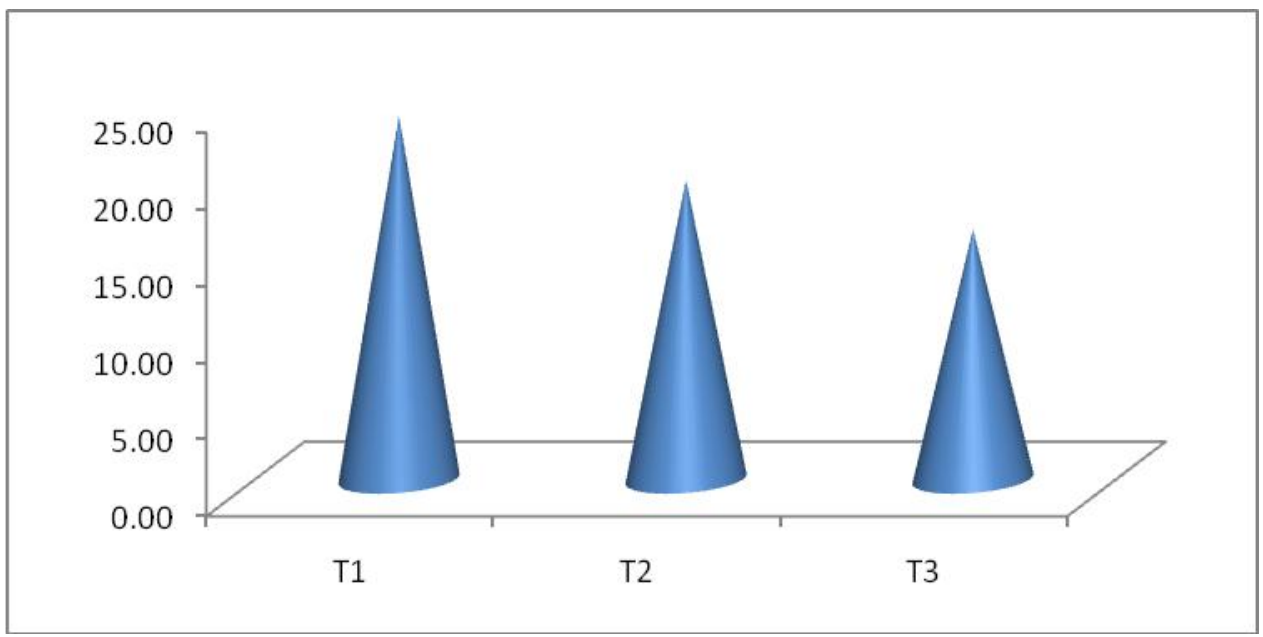


Fig.4 Yield (\%) of freeze dried aloe vera powder

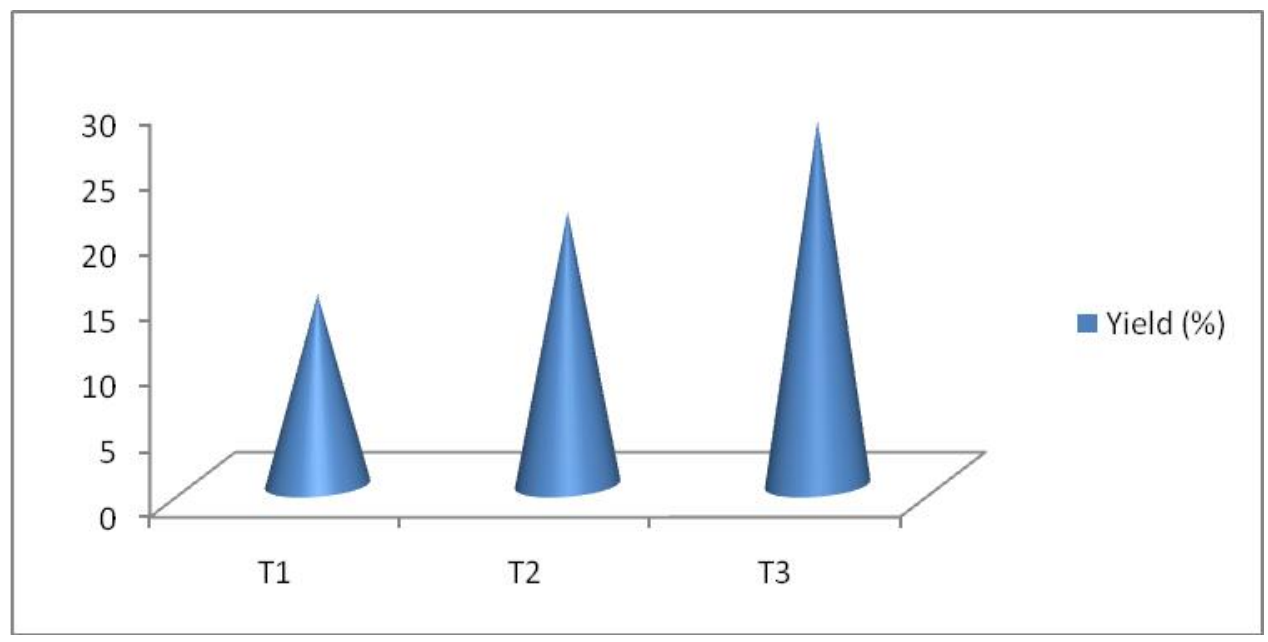

Table.1 Standard values for measuring flowability and cohesiveness of the powder

\begin{tabular}{|l|l|l|l|l|}
\hline CI $(\%)$ & Flowability & HIR & Cohesiveness \\
\hline$<\mathbf{1 5}$ & Very good & $<1.2$ & Low \\
\hline $\mathbf{1 5}-\mathbf{2 0}$ & Good & $1.2-1.4$ & Intermediate \\
\hline $\mathbf{2 0 - 3 5}$ & Fair & $>1.4$ & High \\
\hline $\mathbf{3 5 - 4 5}$ & Bad & & \\
\hline $\mathbf{4 5}$ & Very bad & & \\
\hline
\end{tabular}

Table.2 Physio-chemical and functional properties of freeze dried aloe vera powder

\begin{tabular}{|l|c|c|c|}
\hline \multirow{2}{*}{ Parameter } & \multicolumn{3}{|c|}{ WPI concentration } \\
\hline Moisture Content & $10 \%(\mathrm{T1})$ & $15 \%(\mathrm{~T} 2)$ & $20 \%(\mathrm{~T} 3)$ \\
\hline Water activity & 3.87 & 3.63 & 3.51 \\
\hline Water absorbtion index (g/g) & 0.171 & 0.159 & 0.148 \\
\hline Water solubility index (\%) & 3.36 & 3.16 & 2.99 \\
\hline Swelling capacity (\%) & 84.01 & 84.99 & 87.23 \\
\hline Hygroscopicity (g/100g) & 2.62 & 2.77 & 2.98 \\
\hline Dissolution (s) & 7.96 & 6.88 & 6.02 \\
\hline $\mathbf{L}^{*}$ [whiteness (+)/darkness (-)] & 21.67 & 22.91 & 25.72 \\
\hline $\mathbf{a}^{*}[$ redness (+)/greenness (-)] & 80.68 & 81.33 & 81.66 \\
\hline $\mathbf{b}^{*}$ [vellowness (+)/slueness (-)] & 1.39 & 1.33 & 1.29 \\
\hline
\end{tabular}

$* \mathrm{~T}_{1}$ (Aloe vera $\left.: \mathrm{WPI}:: 90: 10\right) ; \mathrm{T}_{2}$ (Aloe vera $\left.: \mathrm{WPI}:: 85: 15\right) ; \mathrm{T}_{3}$ (Aloe vera $: \mathrm{WPI}:: 80: 20$ )

It was observed that with addition and increase in concentration of carrier agent, $\mathrm{L}^{*}$ value increased. Highest $\mathrm{L}^{*}$ value (81.66) was observed in $\mathrm{T}_{3}$ and the lowest (80.68) was observed in $\mathrm{T}_{1} . \mathrm{a}^{*}$ and $\mathrm{b}^{*}$ values decreased with the addition of WPI. Maximum $\mathrm{a}^{*}$ value (1.39) and $b^{*}$ value (21.35) was observed in $\mathrm{T}_{1}$ and the minimum (1.29 and 20.74) was 
observed in $\mathrm{T}_{3}$ respectively (Table 2 ). Idham et al., (2012) reported the similar decreasing trend for $\left(\mathrm{a}^{*}\right.$ and $\left.\mathrm{b}^{*}\right)$ in anthocyanins from Hibiscus sabdariffa $L$. with increased concentration of carrier agent.

\section{Bulk density and tapped density}

Highest bulk and tapped density (0.36 and $0.43 \mathrm{~g} / \mathrm{ml}$ ) was recorded in $\mathrm{T}_{3}$ and the lowest $(0.29$ and $0.38 \mathrm{~g} / \mathrm{ml})$ in $\mathrm{T}_{1}$ respectively. Increased concentration of whey protein increased the bulk and tapped density. Bulk density of powders is affected by chemical composition, particle size and moisture content as well as by processing and storage conditions (Beristain et al., 2001).

In principle, density increases as volume decreases at a given constant mass. In the present study, bulk densities of powders, increased gradually as the ratio of carrier agents increased (Fig. 1).

Bulk density increased with increased concentration of carrier agent in dried pink guava and avocado oil (Shishir et al., 2014; Bae and Lee, 2008). Tapped density corresponds to the real solid density and does not consider the spaces between the particles, in contrast to the bulk density, which takes into account all these spaces (Cynthia et al., 2015). Tapped density increased with increase in carrier agent (Fig. 1) due to increase in weight of end product in ber powder (Singh et al., 2014).

\section{Cohesiveness (Hausner ratio) and Carr index (CI\%)}

With the increase in concentration of carrier agents, the mean Hausner ratio (Fig. 2) and Carr index (Fig. 3) of freeze dried powder decreased significantly. Highest Hausner ratio and Carr index was recorded in $\mathrm{T}_{1}$ and the lowest Hausner ratio and Carr index in $\mathrm{T}_{3}$.

\section{Powder recovery/yield}

Highest yield (27.32 \%) of freeze dried powder was recorded in $\mathrm{T}_{3}$ and the lowest $(14.53 \%)$ in $T_{1}$. Significant increase in the yield percentage was observed with increase in concentration of whey protein isolate (Fig. 4).

Aloe vera powder was produced using freeze drying technique at three whey protein concentration. Whey protein isolate was an effective drying aid helped in reducing stickiness and altered the physicochemical properties of the aloe vera powder. With increase in concentration of WPI, the moisture content of the freeze dried powder decreased, whereas time for reconstitution increased. Solubility and lightness $\left(\mathrm{L}^{*}\right)$ of the powder was increased with increasing concentration of WPI. Storage also had significant effect on the properties of the freeze dried powder. Moisture content, water activity, dissolution time bulk and tapped density increased with time while solubility and lightness of the product decreased.

\section{Acknowledgement}

The corresponding author greatly acknowledges the financial support from the University Grants Commission (UGC) under the scheme of Maulana Azad National Fellowship for Minority Students (MANF).

\section{References}

Adhikari, B., Howes, T., Bhandari, B.-R., Truong, V. Characterization of the surface stickiness of fructosemaltodextrin solutions during drying. Drying Technology: 2003, 21, 17-34.

Ahmed, M., Aktera, M.-S., Lee, J.-C., Euna, J.B. Encapsulation by spray drying of bioactive components, physicochemical and morphological properties from purple 
sweet potato. LWT - Food Science and Technology: 2010, 43, 1307-1312.

Anderson, R.-A., Conway, H.-F., Griffin, E.-L. Gelatinization of corn grits by roll and extrusion cooking. J Cereal Sci. 1969, 14, 4-12.

Bae, E.-K., Lee, S.-J. Microencapsulation of avocado oil by spray drying using whey protein and maltodextrin. Journal of Microencapsulation. 2008, 25(8), 549560.

Bazaria, B., Kumar, P. Effect of whey protein concentrate as drying aid and drying parameters on physicochemical and functional properties of spray dried beetroot juice concentrate. Food Bioscience. 2016, 14, 21-27.

Beristain, C.-I., Garcia, H.-S., Vernon-Carter, E.-J. Spray-dried encapsulation of cardamom (Elettaria cardamomum) essential oil with mesquite (Prosopis juliora) gum. Lebensmittel-WissenschaftundTechnologie. 2001, 34, 398-401.

Bernard, C., Regnault, S., Gendreau, S., Charbonneau, S. and Relkin, P. Enhancement of emulsifying properties of whey proteins by controlling spraydrying parameters. Food Hydrocolloids. 2011, 25, 758-763.

Bhusari, S.-N., Muzaffar, K. Kumar, P. Effect of carrier agents on physical and microstructural properties of spray dried tamarind pulp powder. Powder Technology. 2014, 266, 354-364.

Cai, Y.-Z., Corke, H. Production and properties of spray-dried Amaranthus betacyanin pigments. Journal of Food Science. 2000, 65 (6), 1248-1252.

Cynthia, S.-J., Bosco, J.-D., Bhol. S. Physical and structural properties of spray dried tamarind (Tamarindus indica L.) pulp extract powder with encapsulating hydrocolloids. International Journal of Food Properties. 2015, 18, 1793-1800.

Eshun, K., He, Q. Aloe Vera: a valuable ingredient for the food, pharmaceutical and cosmetic industries-A Review, Critical Reviews in Food Science and Nutrition. 2004, 44 (2), 91-96.
Fazaeli, M., Emam-Djomeh, Z., Ashtari, A.-K., Omid, M. Effect of spray drying conditions and feed composition on the physical properties of black mulberry juice powder. Food and Bioproducts Processing. 2012, 90, 667-675.

Goula, M.-A. Adamopoulos, K.-G. Effect of maltodextrin addition during spray drying of tomato pulp in dehumidified air: II powder properties. Drying Technology. 2008, 26; 726-737.

Gunaratne, A., Hoover, R. Effect of heatmoisture treatment on the structure and physicochemical properties of tuber and root starches. Carbohydrate Polymers. 2002, 49, 425-437.

Idham, Z., Idayu, M.-I., Sarmidi, R.-M. Degradation kinetics and color stability of spray-dried encapsulated anthocyanins from Hibiscus sabdariffa. Journal of Food Process Engineering. 2012, 35, 522-542.

Jinapong, N., Suphantharika, M., Jamnong, P. Production of instant soymilk powders by ultrafiltration, spray drying and fluidized bed agglomeration. Journal of Food Engineering. 2008, 84 (2), 194-205.

Lai, H.-M., Cheng, H.-H. Properties of pregelatinized rice flour made by hot air or gum puffing. International Journal of Food Science and Technology. 2004, 39, 201-212.

Laokuldilok, T., Kanha, N. Effects of processing conditions on powder properties of black glutinous rice (Oryza sativa L.) bran anthocyanins produced by spray drying and freeze drying, $L W T$ Food Science and Technology, 2015, 64, 405-411.

Lopez-Quiroga, E., Antelo, L.-T., Alonso, A.A. Time-scale modeling and optimal control offreeze-drying. Journal of Food Engineering. 2012, 111, 655-666.

Oberoi, D.-P.-S., Sogi, D.-S. Effect of drying methods and malt dextrin concentration on pigment content of watermelon juice powder. Journal of Food Engineering, 2015, 165, 172-178. 
Ozdikicierler, O., Dirim, S.-N., Pazir, F. The effects of spray drying process parameters on the characteristic process indices and rheological powder properties of microencapsulated plant (Gypsophila) extract powder Powder Technology. 2014, 253, 474-480.

Patras, A., Brunton, N.-P., Tiwari, B.-K., Butler, F. Stability and degradation kinetics of bioactive compounds and colour in strawberry jam during storage. Food Bioprocess Technol. 2011, 4, 12451252.

Phoungchandang, S., Sertwasana, A. Spraydrying of ginger juice and physicochemical properties of ginger powders. Science Asia. 2010, 36: 40-45.

Pugh, N., Ross, S.-A., El-Sohly, M.-A., Pasco, D.-S. Characterization of aloeride, a new high molecular weight polysaccharide from Aloe vera with potent immune stimulatory activity. Journal of Agriculture and Food Chemistry. 2001, 49 (2), 1030-1034.

Quek, A.-Y., Chok, N.-K., Swedlund, P. The physicochemical properties of spray dried watermelon powders. Chem. Eng. Process. 2007, 46, 386-392.

Ramachandra, C.-T., Srinivasa, R.-P. Processing of Aloe vera leaf gel: A review. American Journal of Agriculture and Biological Sciences. 2008, 3 (2), 502510.

Rocha-Parra, D.-F., Lanari, M.-C., Zamora, M.C., Chirife, J. Influence of storage conditions on phenolic compounds stability, antioxidant capacity and colour of freeze-dried encapsulated red wine,
LWT - Food Science and Technology. 2016, 70, 162-70.

Rodríguez-Hernández, G.-R., Gonzalez-Garcia, R., Grajales-Lagunes, A., Ruiz-Cabrera, M.-A., Abud-Archila, M. Spray-drying of cactus pear juice (Opuntia streptacantha): effect on the physicochemical properties of powder and reconstituted product. Drying Technology. 2005, 23 (4), 955973.

Sansone, F., Mencherini, T., Picerno, P., d'Amore, M., Aquino, R.-P., Lauro, M.R. Maltodextrin/pectin microparticles by spray drying as carrier for nutraceutical extracts. Journal of Food Engineering. 2011, 105, 468-476.

Shishir, M.-R.-I., Taipa, F.-S., Aziza, N.-A., Taliba, R.-A. Physical properties of spray-dried pink guava (Psidium guajava) powder. Agriculture and Agricultural Science Procedia 2. 2014, 74 - 81.

Singh, V.-K., Pandey, S., Pare, A., Singh R.B. Optimization of process parameters for the production of spray dried Ber (Ziziphus jujube L.) powder. J Food Sci Technol. 2014, 51 (12), 3956-3962.

Vanzo, A., Garciaa, L., Hubingera, M. 2009. Coffee oil microencapsulation using spray dryer. http://www.icef11.org/ content/papers/fms/FMS949.pdf (assessed on March 16, 2018).

Vidović, S.-S., Vladić, J.-Z., Vaštag, Ž.-G., Zeković, Z.-P., Popović, L.-M. Maltodextrin as a carrier of health benefit compounds in Satureja montana dry powder extract obtained by spray drying technique. Powder Technology. 2014, 258, 209-215.

\section{How to cite this article:}

Ankit Dayal, Anju Bhat, Rafia Rashid, Jagmohan Singh and Sushil Sharma. 2018. Effect of Whey Protein Isolate on the Properties of Freeze Dried aloe vera (Aloe barbadensis Mill) Powder. Int.J.Curr.Microbiol.App.Sci. 7(04): 2071-2079. doi: https://doi.org/10.20546/ijcmas.2018.704.237 